\title{
Measuring Intangibles' Productivity \\ EMPIRICAL EVIDENCE FROM SPANISH FIRMS
}

\author{
Ester Oliveras \\ Universitat Pompeu Fabra
}

David Castillo

Universitat Oberta de Catalunya

\begin{abstract}
As companies and shareholders begin to note the potential repercussions of intangible assets upon business results, the inability of the traditional financial statement model to reflect these new ways of creating business value has become evident. Companies have widely adopted new management tools, covering in this way the inability of the traditional financial statement model to reflect these new ways of creating business value.

However, there are few prior studies measuring on a quantifiable manner the level of productivity unexplained in the financial statements. In this study, we measure the effect of intangible assets on productivity using data from Spanish firms selected randomly by size and sector over a ten-year period, from 1995 to 2004. Through a sample of more than 10,000 Spanish firms we analyse to what extent labour productivity can be explained by physical capital deepening, by quantified intangible capital deepening and by firm's economic efficiency (or total factor productivity -PTF).

Our results confirm the hypothesis that PTF weigh has increased during the period studied, especially on those firms that have experienced a significant raise in quantified intangible capital, evidencing that there are some important complementary effects between capital investment and intangible resources in the explanation of productivity growth. These results have significant differences considering economic sector and firm's dimension.
\end{abstract}

Keywords: intangibles, accounting, Spain.

Journal of Economic Literature Classifications: M41 


\section{Introducción}

The development of the knowledge-based economy has led to a change in how companies create value. During the industrial revolution and throughout much of the period of time which has elapsed since then, businesses created value principally through the efficient use of physical resources such as raw materials and machinery. Nowadays value is increasingly likely to be created by using human know-how to exploit less tangible assets such as brands or information systems. These newer and more predominant sources of value can be described by the generic term 'knowledge'.

Whilst, clearly, "knowledge" has always existed, it has only been in recent decades that the asset has been identified as the main generator of value (Stewart, 1997). How has this change come about? According to Lev (2001), there are two reasons: first, due to the increase in business competition arising from globalisation and increasing deregulation of many sectors and, second, due to the appearance of new information systems and technological advances. One example of this is provided by Ford, which has, in recent years, embarked upon a process of accelerated vertical disintegration, subcontracting out a large part of its production and selling material assets which are no longer required in its new structure. These changes have allowed the company to return 10 billion euros to its shareholders. Additionally, Ford has invested in the acquisition of intangible assets, above all brands, such as Jaguar, Volvo and Land Rover.

This restructuring has only been made possible by the intensive use of information systems and the Internet.

An organisation's business knowledge can be called by a variety of names, of which "intellectual capital"(IC) and "intangible assets" are the most common. These two expressions, for practical purposes are often regarded as being virtually synonymous. A company's intellectual capital will include elements such as the know-how and abilities of its workers, experience, information and the structure or learning capacity of the organisation. A formalised definition of intangible assets is provided by Itami (1994), who describes them as "the result of incorporating information and knowhow into a organisation's productive activities, including that tacit and explicit knowledge which generates economic value for the company".

\section{Intangible assets as productivity factors}


As companies and shareholders begin to note the potential repercussions of intangible assets upon business results, the inability of the traditional financial statement model to reflect these new ways of creating business value has become evident. The fact is that current accounting regulations do not permit inclusion of a large part of the intangible assets acquired or produced by a company. Roslender and Fincham (2001) are pessimistic about the possibility of financial accounting ever being able to encompass intellectual capital. Furthermore, it is clear that the accounting classifications currently employed in financial statements are woefully inadequate in describing intangibles. Indeed, as observed by Gröjer (2001): "a classification of all possible intangibles does not seem to be a task within the limits of realisation".

According to research carried out by Lev (2001), intangible assets could represent as much as between 60 and 75 percent of business assets. Handy (1989) goes further by suggesting that the value of $\mathrm{IC}$ is normally three or four times the book value of a company and that efficient and effective management of these assets will become the only way of maintaining a competitive advantage. Given the importance intangibles have acquired in recent years, traditional financial indicators are no longer sufficient as indicators of the strategic position of a business or as measurements of the long-term value and state of a company.

There can be little doubt of the significance of intangible assets in most businesses. For example, Catasús and Gröjer (2001) assess decisions made on the granting of credits by financial institutions on the basis of the type of accounting information submitted. The results point to the fact that accounting for intangibles may have considerable importance in the taking of financing-related decisions Equally, it must be recognised that while both management and financial accounting systems fail to measure and report IC, corporate managers may be making suboptimal decisions about the use of resources (van der Meer-Kooistra and Zijlstra, 2001).Although an analysis of available literature shows that there is general agreement on the strategic importance of intangible assets, it should be noted that there is wide-ranging debate as to which are the most suitable tools for measuring and reporting intellectual capital. Bontis (1998) explains that the challenge for academics in the field is to develop theories to be able to treat this highly ambiguous concept more rigorously. As Stewart (1997) points out: 'Intellectual capital has been considered by many, defined by some, understood by few and valued by practically nobody'.

The most intuitively obvious measurement of the value of intellectual capital has been identified with the difference between a company's market and net book values (Holland, 2001) It can often be demonstrated that the companies with the greatest differences between these values have high levels of intellectual capital. For example, in June 2000, Microsoft's physical and financial assets represented less that $10 \%$ of its market value, and those of Cisco only $5 \%$ (Lev, 2001). 
The main disadvantage of measurements such as goodwill or the difference between market and net book values is that they provide no information about the composition of the intangible assets. Whilst, for some companies, a large amount of the difference between market and net book values may come from a brand (such as Coca-Cola or Microsoft), for others it may come from know-how or patents, as is the case with the pharmaceutical industry. If managers do not know what their intangibles comprise, it will be difficult to manage them efficiently.

\section{IC: disclosures}

The measurement approaches outlined above are based on two highly questionable assumptions. The first is that the market value of a company is efficient and does not reflect the possible effect of the general market situation or political matters. The second limitation is that it does not take into account the fact that tangible assets are often valued on a historic cost basis, due to applicable accounting regulations, and that this may lead to a lower book value.

value and book value, such a measurement tells the observer nothing about the constituent elements of IC. Any attempt to identify separately the key elements would be, in most cases, highly subjective. An alternative to measurement and full recognition of IC is to augment disclosures in the annual report, or by means of separate reports. In the last ten to fifteen years, various attempts have been made to provide useful statements of firms' IC resources. A thorough review of the various intellectual capital frameworks is provided in Brennan and Connell (2000), and what follows here is a much briefer review. The case of Skandia, a Swedish insurance company, is often cited as an early example of the development of IC disclosure. Edvinsson (1997) describes the search for a satisfactory approach to identification and measurement of IC by Skandia's corporate management. The process resulted in the identification of two principal elements in IC: human capital and structural capital, the latter being the dimensions that were 'left behind when the staff went home' (p. 368). The disclosure that resulted from the analysis incorporated both narrative and numerical elements. The Skandia approach has been influential: for example, van der MeerKooistra and Zijlstra (2001) describe the development of a Dutch framework for IC reporting based on the Skandia model. Nordic countries have tended to lead the way in IC reporting. For example, Bukh (2003) describes the initiative led by the Danish Agency for the Development of Trade and Industry to develop guidelines for the publication of intellectual capital statements.

Sveiby (1996 - 2003) developed the Intangible Assets Monitor, which focuses upon three categories of intangible asset: external structure, internal structure and employee competence.

\section{Accounting for intangible assets}

\subsection{Intangible assets and financial accounting}


Internationally, progress is slow in respect of the development of accounting standards on IC measurement and reporting. There is a growing recognition amongst many academics that traditional financial statements are obsolete for both investors and management. For example, Lev (2001) points to the fact that measures on the management of intellectual capital provide more relevant information than the profit and loss account or the funds flow statement. The author analyses the link between the extent of investment in research and development (RD), and business results. The results of the analysis show that, in the USA, companies that invest in R\&D obtain profits up to four times greater than companies that make no such investment.

Recent developments in regulation reflect some understanding by regulators of the importance of intangibles. For example, the Financial Accounting Standards Board (FASB), the USA's leading regulatory body, has published new recommendations affecting intangible assets, with a view to ensuring that their accounting treatment provides a truer reflection of a business's situation. For example, amortisation of goodwill and other intangible assets is no longer compulsory, should these assets not depreciate (FASB, 2001). There is also a provision for the capitalisation of software development costs. International standards are tending to follow a similar approach: IFRS 3 Business Combinations has followed the US approach in respect of the capitalisation of goodwill.

\subsection{Intangible assets and management accounting}

Apart from the above standards, there is no other type of international or local regulations governing the identification and measurement of an organisation's intangibles. One noteworthy initiative is the Meritum Project (2002), financed by the European Union between 1998 and 2001, which brings together academics and professionals from different countries to create a guide for companies interested in implementing intellectual capital management systems. In light of the project's success, a second has been commenced, dubbed E-know net. It should be noted that these project have enjoyed the collaboration of companies such as Bankinter, BBVA, Banco Santander Central Hispano and KPMG, amongst others.

\section{Previous research on productivity for intangible assets}

As we have seen intangible assets are not visible and not reported in the financial statements. Our hypothesis is that these assets should provide real returns in the form of higher output. Therefore, the production function should reveal that firms have put in place more of these intangibles saw greater output in subsequent years, discounting accounting standard data (Brynjolfsson, Hitt, Yang; 2002).

Previous economic literature show tha IC factors have an important impact on productivity. For example, Lev and Sougiannis (1996) showed evidence that R\&D investments brings benefits to listed companies in the form of market valuation. 
Bryjolfsson and Hitt (20??) mesure the effect of computerization on productivity in the US from the mid-80s until mid-90s. The results show that short-term differences in productivity are normal returns to computar investments. However, long-term productivity is much higher. The authors suggest that this "unexplained" growth in productivity is due to other investments not included in the calculations of productivity, such as organizational capital.

In Spain, no such measurement has been yet carried out. In our analysis, we

The productivity measurement of intangibles has been studied previously by

\section{Methodology}

\section{Results}

\section{Conclusions}

\section{References}

Brynjolfsson, E.; Hitt, L.M. (???2003) Computing productivity: Firm-Level evidence, Review of Economics and Statistics. ???

Brynjolfsson, E., Hitt, L.M., Yang, S. (2002) Brookings Papers on Economic Activity.

Abeysekera, I. and Guthrie. J. (2005), "An empirical investigation of annual reporting trends of intellectual capital in Sri Lanka", Critical Perspectives on Accounting, Vol. 16, No. 3, pp. 151-163.

Bontis, N. (1998), "Intellectual capital: an exploratory study that develops measures and models" Management Decision, 36/2, pp. 63-76.

Bontis, N. (2002), "Intellectual capital disclosure in Canadian corporations", unpublished paper.

Brennan, N. (2001), "Reporting intellectual capital in annual reports: evidence from Ireland" Accounting, Auditing and Accountability Journal, Vol. 14, No. 4, pp. 423-436. 
Brennan, N. and Connell, B. (2000), "Intellectual capital: current issues and policy implications", Journal of Intellectual Capital, Vol. 1, No. 3, pp. 206-240.

Bukh, P.N. (2003), "The relevance of intellectual capital disclosure: a paradox?", Accounting, Auditing and Accountability Journal, Vol. 16, No. 1, pp. 49-56.

Catasús, B. and Gröjer, J.E. (2001), "Intangibles and Credit Decisions - results from a field experiment", Paper presented at the European Accounting Association Congress, Athens.

Edvinsson, L. (1997), “Developing intellectual capital at Skandia”, Long Range Planning, Vol. 30, No. 3, pp. 366-373.

FASB (2001), Summary of Statement No. 142. Goodwill and Other Intangible Assets Financial Accounting Standards Board.

Gallego, I. and Rodríguez, L. (2005), "Situation of intangible assets in Spanish firms: an empirical analysis", Journal of Intellectual Capital, Vol. 6, No.1, pp. 105-126.

Goh, P.C. and Lim, K.P. (2004), "Disclosing intellectual capital in company annual reports", Journal of Intellectual Capital, Vol. 5, No. 3, pp. 500-510.

Gröjer, J.-E. (2001), "Intangibles and accounting classifications: in search of a classification strategy", Accounting, Organizations and Society, 26, pp. 695-713.

Guthrie, J. and R. Petty (2000), "Intellectual capital: Australian annual reporting practices" Journal of Intellectual Capital, Vol. 1, No. 3, pp. 241-251.

Guthrie, J. Petty, R., Yongvanich, K. and Ricceri, F. (2004) "Using content analysis as a research method to inquire into intellectual capital reporting", Journal of Intellectual Capital, Vol. 5, No. 2, pp. 282-293.

Handy, C.B. (1989), The Age of Unreason, Arrow Books Ltd., London.

Holland, J. (2001), "Corporate Value Creation, Intangibles, and valuation: a dynamic model of corporate value creation and disclosure" paper presented at the European Accounting Association Conference, Athens.

Itami, H. (1994), "Los activos invisibles" in Campbell, A. and Luchs, K. Sinergia Estratégica de Identificar Oportunidades, Deusto, Bilbao.

Lev, B. (2001), Intangibles: Management, Measurement, and Reporting, Brookings Institution Press.

Meritum Project (2002), Guidelines for managing and reporting on intangibles, Ed. Fundación Airtel Móvil.

OECD (2005), Factbook 2005, excerpts accessed 25.4 .05 at http://hermia.sourceoecd.org

Ordóñez de Pablos, P. (2003), "Intellectual capital reporting in Spain: a comparative view", Journal of Intellectual Capital, Vol. 4, No. 1, pp. 61-81.

Roslender, R. and Fincham, R. (2001), "Thinking critically about intellectual capital accounting", Accounting, Auditing and Accountability Journal, Vol. 14, No.4, pp. 383-398.

Stewart, T.A. (1997), Intellectual Capital: The New Wealth of Organizations, Doubleday/Currency, New York.

Sveiby, K-E. (1996, 1997, 2001, 2003), "Creating value with The Intangible Assets Monitor", accessed 4.5 .05 at www.sveiby.com/articles/companymonitor.html.

van der Meer-Kooistra, J. and Zijlstra, S.M. (2001), "Reporting on intellectual capital", Accounting, Auditing and Accountability Journal, Vol. 14, No. 4, pp. 456-476.

Vergauwen, P.G.M.C. and van Alem, F.J.C. (2005), "Annual report IC disclosures in The Netherlands, France and Germany”, Journal of Intellectual Capital, Vol. 6, No. 1, pp. 89-104. 
